\title{
Characterization of $\mathrm{Ag}$-promoted $\mathrm{Ni} / \mathrm{SiO}_{2}$ Catalysts for Syngas Production via Carbon Dioxide $\left(\mathrm{CO}_{2}\right)$ Dry Reforming of Glycerol
}

\author{
Norazimah Harun ${ }^{1}$, Jolius Gimbun 1,2, Mohammad Tazli Azizan², \\ Sumaiya Zainal Abidin 1,2 * \\ ${ }^{1}$ Faculty of Chemical Engineering \& Natural Resources, Universiti Malaysia Pahang, 26300 \\ Gambang, Pahang, Malaysia \\ ${ }^{2}$ Centre of Excellence for Advanced Research in Fluid Flow (CARIFF), Universiti Malaysia \\ Pahang, 26300 Gambang, Pahang, Malaysia \\ ${ }^{3}$ Department of Chemical Engineering, Faculty of Engineering, Universiti Teknologi PETRONAS, \\ 32610 Bandar Seri Iskandar, Perak Darul Ridzuan, Malaysia
}

Received: 22 $2^{\text {nd }}$ January 2016; Revised: 22 ${ }^{\text {nd }}$ February 2016; Accepted: 23rd February 2016

\section{Abstract}

The carbon dioxide $\left(\mathrm{CO}_{2}\right)$ dry reforming of glycerol for syngas production is one of the promising ways to benefit the oversupply crisis of glycerol worldwide. It is an attractive process as it converts carbon dioxide, a greenhouse gas into a synthesis gas and simultaneously removed from the carbon biosphere cycle. In this study, the glycerol dry reforming was carried out using Silver (Ag) promoted Nickel (Ni) based catalysts supported on silicon oxide $\left(\mathrm{SiO}_{2}\right)$, i.e. $\mathrm{Ag}-\mathrm{Ni} / \mathrm{SiO}_{2}$. The catalysts were prepared through wet impregnation method and characterized by using Brunauer-Emmett-Teller (BET) surface area, Scanning Electron Microscopy (SEM), X-ray Diffraction (XRD), and Thermo Gravimetric (TGA) analysis. The experiment was conducted in a tubular reactor which condition fixed at $973 \mathrm{~K}$ and $\mathrm{CO}_{2}$ to glycerol molar ratio of 1 , under atmospheric pressure. It was found that the main gaseous products are $\mathrm{H}_{2}$, $\mathrm{CO}$ and $\mathrm{CH}_{4}$ with $\mathrm{H}_{2}$ : $\mathrm{CO}$ molar ratio < 1.0. From the reaction study, $\mathrm{Ag}(5)-\mathrm{Ni} / \mathrm{SiO}_{2}$ results in highest glycerol conversion and hydrogen yield, accounted for $32.6 \%$ and $27.4 \%$, respectively. Copyright (C) 2016 BCREC GROUP. All rights reserved

Keywords: Glycerol; Dry reforming; Syngas; Nickel-based catalysts; Silicon Oxide

How to Cite: Harun, N., Gimbun, J., Azizan, M.T., Abidin, S.Z. (2016). Characterization of Agpromoted Ni/SiO 2 Catalysts for Syngas Production via Carbon Dioxide $\left(\mathrm{CO}_{2}\right)$ Dry Reforming of Glycerol. Bulletin of Chemical Reaction Engineering \& Catalysis, 11 (2): 220-229

(doi:10.9767/bcrec.11.2.553.220-229)

Permalink/DOI: http://dx.doi.org/10.9767/bcrec.11.2.553.220-229

\section{Introduction}

Fossil fuels such as coal, crude oil and natural gas are formed from the remains of dead plants and animals over million years ago. It has been utilized as energy resources globally

* Corresponding Author.

E-mail: sumaiya@ump.edu.my

Telp: +6095492890, Fax: +6095492889 for the past decades. World has relied on this non-renewable energy as the primary fuel source for the electricity, heating and powering vehicles. However, increasing global energy consumption as a result of rising population growth may lead to the depletion of fossil-based resources in the near future. Moreover, the risk of global climate change rises as global consumption rises. It is believed that carbon emissions from fossil fuels are the main factor for 
the rise in atmospheric concentrations and global temperatures. Today, renewable energy sources especially biomass have been gaining attention as an alternative for fossil fuels consumption [1]. As the most viable alternative fuel, biodiesel is considered as a promising alternative energy. Biodiesel is produced industrially through transesterification of vegetable oil (edible oil) and non-edible oil, where the side product is glycerol. Approximately $10 \mathrm{wt} \%$ of crude glycerol constituted from the total product. Therefore increasing demands of biodiesel contribute to a dramatic growth in glycerol production.

The production of synthesis gas (syngas) and hydrogen is a promising way to benefit oversupply of glycerol production. Syngas is a gas mixture constitutes of carbon monoxide, carbon dioxide and hydrogen. It is widely used as intermediates in creating synthetic natural gas and petroleum and for the production of ammonia and methanol [2]. The most common method of producing hydrogen and syngas using is through steam reforming. However, this endothermic process requires high-energy consumption in order to provide optimum condition for reaction to occur. This high reaction temperature, in the other way promotes the formation of carbon which negatively affect the stability of the catalyst.

The glycerol $\mathrm{CO}_{2}$ dry reforming process is an attractive process as it converts carbon dioxide, a greenhouse gas into a synthesis gas and simultaneously removed from the carbon biosphere cycle. Dry reforming of glycerol is an endothermic reaction in which as the temperature increases, the favourable product formed will also be higher. However, to date, there are limited literatures reported on the glycerol dry reforming.

Equation 1 shows the primary reaction occurred in the dry reforming of glycerol:

$$
\begin{array}{r}
\mathrm{C}_{3} \mathrm{H}_{8} \mathrm{O}_{3}+\mathrm{CO}_{2} \rightarrow 4 \mathrm{CO}+3 \mathrm{H}_{2}+\mathrm{H}_{2} \mathrm{O} \\
\Delta \mathrm{H}_{298 \mathrm{~K}}=248.33 \mathrm{~kJ} / \mathrm{mol}
\end{array}
$$

Wang et al. [3] had performed a thermodynamic analysis of glycerol dry reforming. The possible products formed at the end of the process are hydrogen, carbon monoxide, carbon dioxide, methane, water and carbon (solid deposition). It is found that the synthesis gas reached the maximum production at temperature 1000 $\mathrm{K}$ and $\mathrm{CO}_{2}$ : glycerol molar ratio of $1: 1$. Atmospheric pressure was preferable for the system. Glycerol conversion achieved 100\% conversion, while carbon dioxide conversion was increased with the increase of temperature [3].

Lee et al. investigated the glycerol dry reforming over $\mathrm{Ni}$ catalyst supported on cement clinker. They found that addition of $\mathrm{Ni}$ has significantly improved the surface area of the catalyst even though the cement clinker is a non-porous substance. At $1023 \mathrm{~K}$ reaction temperature, hydrogen-to-carbon dioxide ratio is less than 2.0 which is suitable for FischerTropsch synthesis. Unfortunately, side reactions like methanation and hydrogenation of carbon dioxide affected the production of syngas [4].

Glycerol dry reforming over La-promoted $\mathrm{Ni} / \mathrm{Al}_{2} \mathrm{O}_{3}$ catalysts for the production of syngas was conducted by Siew et al. [5]. Catalysts were prepared by wet-impregnation method with promoter loading ranging from 1 to $5 \mathrm{wt} \%$. The study revealed that $3 \% \mathrm{La}-\mathrm{Ni} / \mathrm{Al}_{2} \mathrm{O}_{3}$, which possessedthe largest surface area exhibited the most stable catalytic activity and achieve the optimum hydrogen production and glycerol conversion. It was found that, although production of hydrogen and glycerol increased by addition of La promoter, the addition of promoter over the optimum level led to the reduction of catalytic activity due to clogging in the pores which cover the active sites of the catalyst and thus reduce the catalyst activity.

Selection of suitable catalyst is crucial in every process. Ni-based catalyst is widely used in reforming activities due to highly abundance and low in cost. Moreover, it can work well towards optimum results with introduction of metal promoter. Noble metals ( $\mathrm{Ru}, \mathrm{Pd}, \mathrm{Pt}$ etc.) are often use as the promoter. However, these catalysts are also known to favor the deposition of carbon (coking), which may reduce the performance of the catalyst. $\mathrm{Ag}$ is uncommonly used in dry reforming studies. Nevertheless, $\mathrm{Ag}$ has been reported possessing the ability to inhibit the formation of coke and thus maintain the stability of the catalyst [6, 7]. Moreover, $\mathrm{Ag}$ as the promoter improves the ethanol conversion and hydrogen selectivity in ethanol steam reforming, as reported by Chen et al [8]. This paper is focuses on $\mathrm{CO}_{2}$ dry reforming of glycerol over Ni-based catalyst supported on silicon oxide $\left(\mathrm{SiO}_{2}\right)$ promoted with $\mathrm{Ag}$. It is expected that Ni-based catalyst promoted with Ag enhances the conversion of glycerol and yield of desired gaseous products besides contributes to the stability of the catalyst by minimizing the coke formation. 


\section{Materials and Methods}

\subsection{Materials}

Glycerol (Fisher Scientific, 99.95\% purity) was used as feedstock for the dry reforming process. A series of silver promoted nickelbased catalyst supported on silica was prepared using nickel(II) nitrate hexahydrate (Acros Organics, 99\% purity), silicon oxide (Acros Organics, 99\% purity) and silver nitrate (Acros Organics, 99\% purity). Gaseous carbon dioxide is used as the reactant for the dry reforming process. Since the mass flow rate of carbon dioxide gas is low, inert nitrogen gas had been utilized as carrier gas to facilitate the transportation of reactants through the reactor system.

\subsection{Catalyst preparation}

Silicon oxide was ground and sieved to 250 $\mu \mathrm{m}$ particle sizes beforehand. Prior to wet impregnation method, the oxide support was first calcined at $1073 \mathrm{~K}$ for 6 hours, with ramping rate of $5 \mathrm{~K} \mathrm{~min}^{-1}$ to remove the impurities and to avoid the transition of phase when exposed to high temperature in reforming reaction. The calcined oxide support was then impregnated with the aqueous solution of $\mathrm{Ni}\left(\mathrm{NO}_{3}\right)_{2} \cdot 6 \mathrm{H}_{2} \mathrm{O}$ and $\mathrm{AgNO}_{3}$ to synthesized $15 \mathrm{wt} \%$ Ni-based catalysts with $0-5$ wt\% Ag loadings. The solutions were magnetically stirred for $3 \mathrm{~h}$ at ambient temperature for metal impregnation. Then, the slurries were dried in the oven at temperature of $373 \mathrm{~K}$ overnight. The catalyst was manually stirred using the glass rod during the first six hours using glass rod to avoid particle agglomeration. After that, the dried compound was calcined in the furnace at $773 \mathrm{~K}$ for $5 \mathrm{~h} \mathrm{em}$ ploying heating rate of $5 \mathrm{~K} \mathrm{~min}^{-1}$. The catalysts were cooled down, ground and sieved using 150 $\mu \mathrm{m}$ sieve size.

\subsection{Catalyst characterization}

The surface structure and morphology of the catalysts were captured by using Scanning Electron Microscopy (SEM) JOEL.JSM- 7800F model. Brunauer-Emmet-Teller (BET) analysis was carried out using Thermo-Scientific Surfer to determine the specific surface area of the calcined catalysts where liquid $\mathrm{N}_{2}$ was used as an adsorbate. X-Ray Diffraction (XRD) analysis was conducted using Rigaku Miniflex II to obtain crystalline structure of the catalysts. This analysis was carried out using $\mathrm{CuKa}$ radiation $(\Lambda=1542 \AA)$ at $15 \mathrm{~mA}$ and $30 \mathrm{kV}$. The scan rate was $1^{\circ} \mathrm{min}^{-1}$ for values between $2 \theta=10^{\circ}$ and $80^{\circ}$. The crystallite size was determined using Scherrer equation shown in Equation 2.

$$
d=\frac{K \lambda}{\beta \cos \theta}
$$

where $d$ is the crystallite size, $K$ is the shape factor, $\lambda$ is the $\mathrm{X}$-ray radiation $(\lambda=0.154 \mathrm{~nm}), \beta$ is the full-width at half maximum (FWHM) and $\theta$ is half of diffraction angle. Thermogravimet-

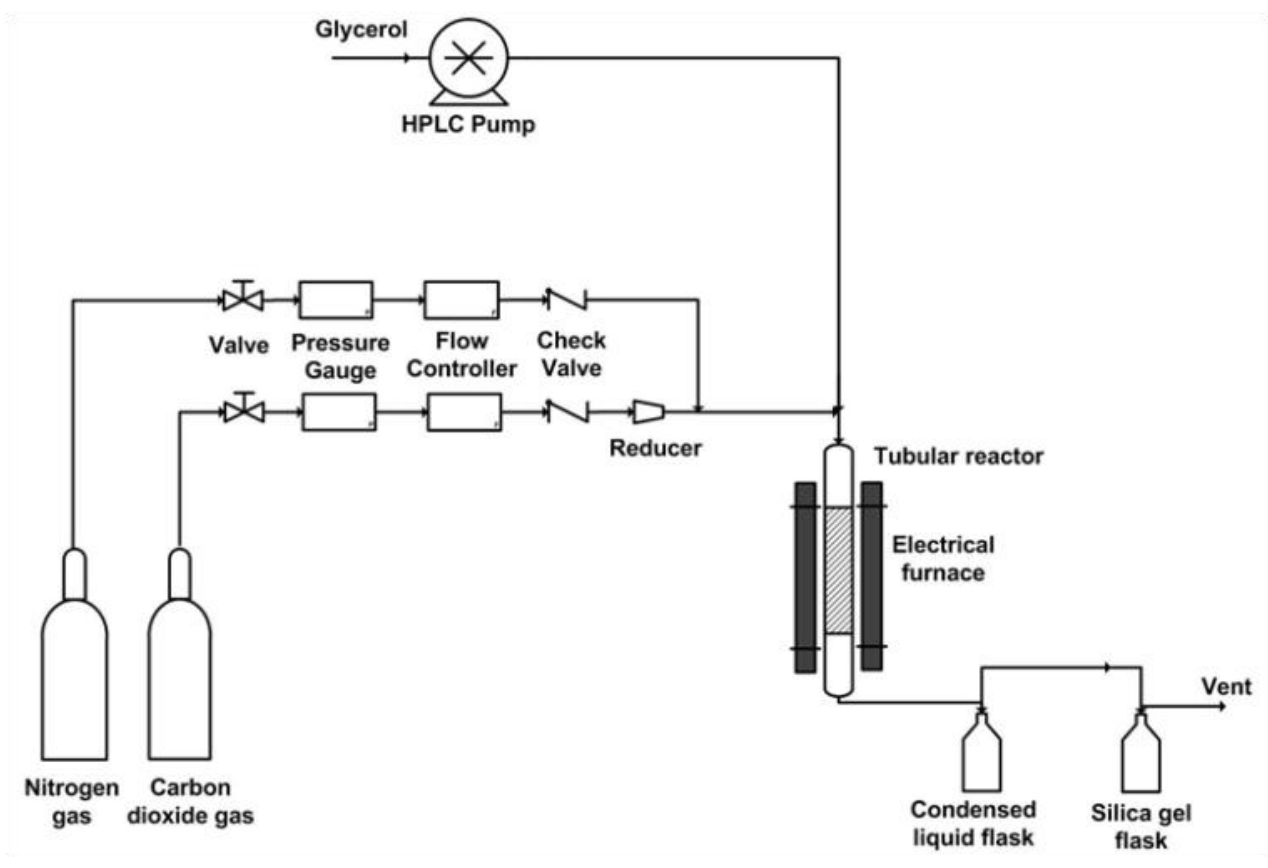

Figure 1. Experimental set-up for glycerol dry reforming 
ric analysis was conducted using the Q500model thermogravimetry analyser, with the ramping rate fixed at $10 \mathrm{~K} \mathrm{~min}^{-1}$. The temperature-programmed reduction (TPR) profiles of the catalysts under $\mathrm{H}_{2}$-blanket were carried out using Thermo Finnigan TPDRO. The ramping rate was fixed at $10 \mathrm{~K} \mathrm{~min}^{-1}$, increasing the temperature from room temperature to $1173 \mathrm{~K}$ followed by $1 \mathrm{~h}$ holding period.

\subsection{Dry reforming experimental work}

The glycerol dry reforming was carried out in a stainless-steel fixed bed reactor (ID $=0.95$ $\mathrm{cm}$; length $40 \mathrm{~cm}$ ) at atmospheric pressure. Figure 1 shows the experimental set-up for glycerol dry reforming. The reaction temperature was fixed at $973 \mathrm{~K}$ and $\mathrm{CO}_{2}$ to glycerol molar ratio of 1:1. The volume flow rate of glycerol was fixed at $0.03 \mathrm{~mL} / \mathrm{min}$ and $100 \mathrm{~mL} / \mathrm{min}$ for $\mathrm{CO}_{2}$. The reactor was loaded with $0.2 \mathrm{~g}$ of catalyst. Prior to reaction, the catalyst was reduced in $50 \mathrm{ml} / \mathrm{min}$ hydrogen for $1 \mathrm{~h}$ at $700{ }^{\circ} \mathrm{C}$. Glycerol was flowed into the reactor using the HPLC pump. The outlet gases were passed through a gas wash bottle which consists of silica gel flask to absorb moisture. The exit gas flow rates was measured using a bubble meter and collected into a gas sampling bag. The composition of syngas produced was determined using online Agilent gas chromatography (GC) with TCD capillary columns, HP-MOLSIV (30.0 $\mathrm{m} \times 530 \mu \mathrm{m} \times 40.0 \mu \mathrm{m})$.

\subsection{Catalytic reaction performance}

The catalyst performance was evaluated based on the glycerol conversion and hydrogen yield. The glycerol conversion to gaseous products was determined based on the atomic $\mathrm{H}$ balance and defined as:

$$
X_{G}=\frac{\left(2 F_{\mathrm{H}_{2}}\right) \times\left(4 F_{\mathrm{CH}_{4}}\right)}{8 F_{\mathrm{C}_{3} \mathrm{H}_{8} \mathrm{O}_{3}}} x 100
$$

The yield of hydrogen is expressed as:

$$
Y_{H_{2}}=\frac{2 F_{H_{2}}}{8 F_{C_{3} H_{8} O_{3}}} x 100
$$

The yield of C-containing yield is expressed as in Equation (5), where $i=\mathrm{CO}, \mathrm{CO}_{2}$ or $\mathrm{CH}_{4}$ :

$$
Y_{i}=\frac{F_{i}}{3 F_{C_{3} H_{8} O_{3}}} x 100
$$

where, $F_{H 2}$ and $F_{C H 4}$ represents molar flow rate of hydrogen and methane product respectively, while $F_{\text {Сзнооз }}$ refers to the molar flow rate of the inlet glycerol.

\section{Results and Discussion}

\subsection{X-Ray Diffraction characterization (XRD)}

Figure 2 shows the crystalline structures of the catalysts depicted by the peaks between $2 \theta$ of $10^{\circ}$ and $80^{\circ}$. The diffraction peaks at $2 \theta$ of $37.3^{\circ}, 43.3^{\circ}, 62.9^{\circ}, 75.4^{\circ}$ and $79.4^{\circ}$ characterize the $\mathrm{NiO}$ phase. $\mathrm{SiO}_{2}$ peak appeared at $2 \theta$ of $21.5^{\circ}$ and this peak was shifted to the right as $\mathrm{Ag}$ loading increases. Other $\mathrm{SiO}_{2}$ phases co-exist with $\mathrm{NiO}$ peaks at the same diffraction angles and possess near-similarity crystalline structure. The metal particles size of the catalysts show no significant change upon addition of Ag. This finding is also confirmed by Parizotto et al. [6]. However, four additional peaks appear at $2 \theta$ of $38.2^{\circ}, 44.4^{\circ}, 64.5^{\circ}$ and $77.5^{\circ}$, which coincide with peaks of $\mathrm{Ag}$. Interestingly, the peaks of $\mathrm{AgSi}$ in $\mathrm{Ag}(1)-\mathrm{Ni} / \mathrm{SiO}_{2}$ and $\mathrm{Ag}(2)-\mathrm{Ni} / \mathrm{SiO}_{2}$ appeared between $2 \theta$ of $29.0^{\circ}$ to $80.0^{\circ}$ are short and unnoticeable, indicates the weak dispersion of $\mathrm{Ag}$ with the catalyst support at low Ag loading. The short peaks indicate the formation of small crystalline particles, which might cover the active sites of the catalyst [9].

\subsection{Scanning Electron Microscopy (SEM)}

The morphology structures of the catalysts at 5000 times magnification are shown in Figure 3. The calcined $\mathrm{SiO}_{2}$ in Figure 3(a) reveals a smooth surface with few crystallites formed. Upon impregnation with $\mathrm{Ni}$, the surface has become rougher and bulkier, and this finding suggests the formation of $\mathrm{NiO}$ crystallites. Larger particles formation are observed on the promoted catalysts (in Figure 3(c) and (d)) which indicates the agglomeration of $\mathrm{AgSi}$ and $\mathrm{Ag}$ crystallites besides the smaller $\mathrm{NiO}$ crystallites. The surface of $\mathrm{Ag}(5)-\mathrm{Ni} / \mathrm{SiO}_{2}$ is rougher and bulkier compared to $\mathrm{Ag}(1)-\mathrm{Ni} / \mathrm{SiO}_{2}$ due to the higher Ag loading. This results were co-current with the findings from XRD analysis, where it shows the presence of large $\mathrm{Ag}$ particles at higher Ag loading and it was represented by the additional peaks appear at $2 \theta$ of $38.2^{\circ}, 44.4^{\circ}$, $64.5^{\circ}$ and $77.5^{\circ}$. 


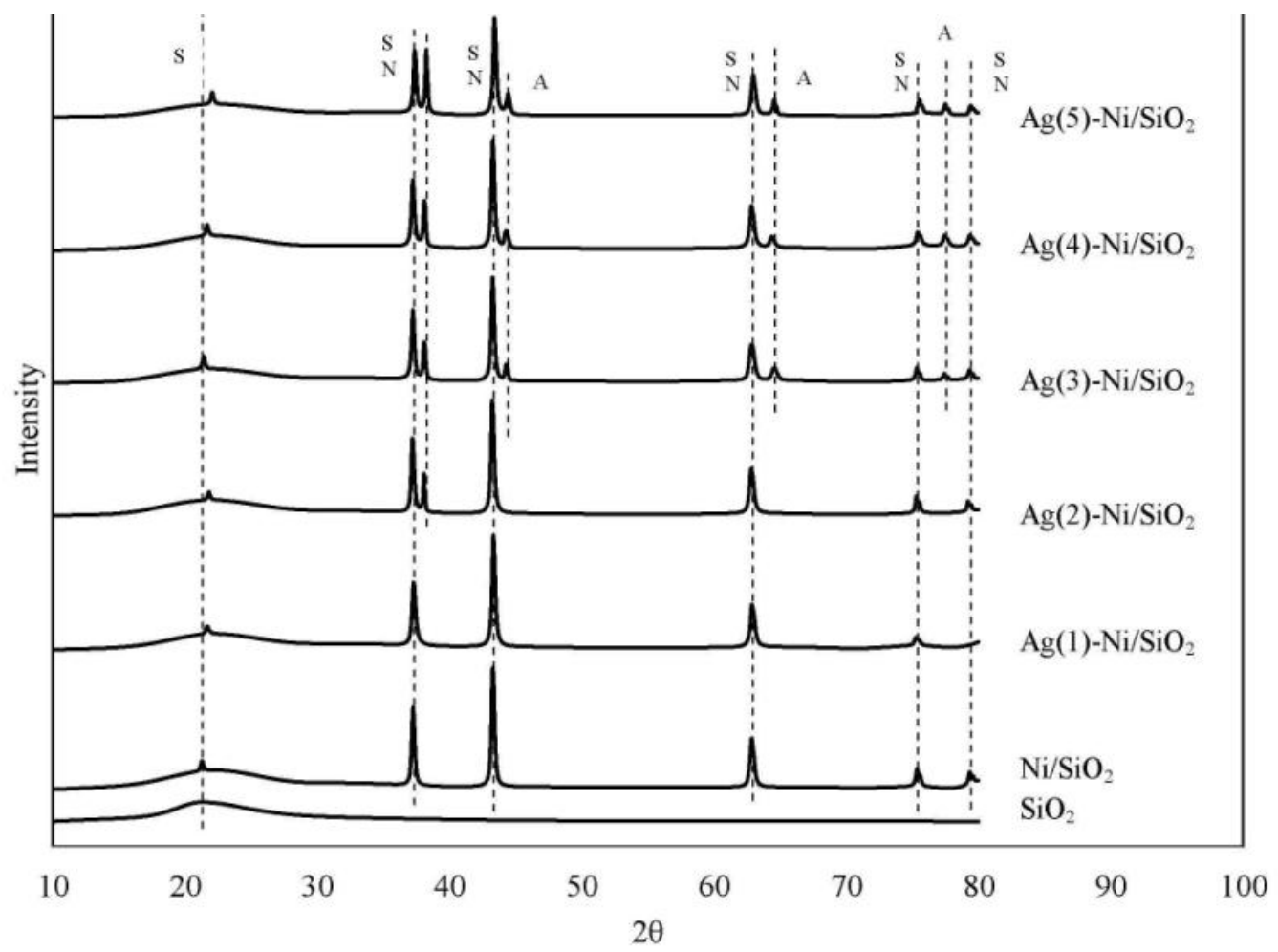

Figure 2. XRD pattern for the prepared catalysts. ( $\mathrm{S}-\mathrm{SiO}_{2}, \mathrm{~N}-\mathrm{NiO}$, and A-Ag)
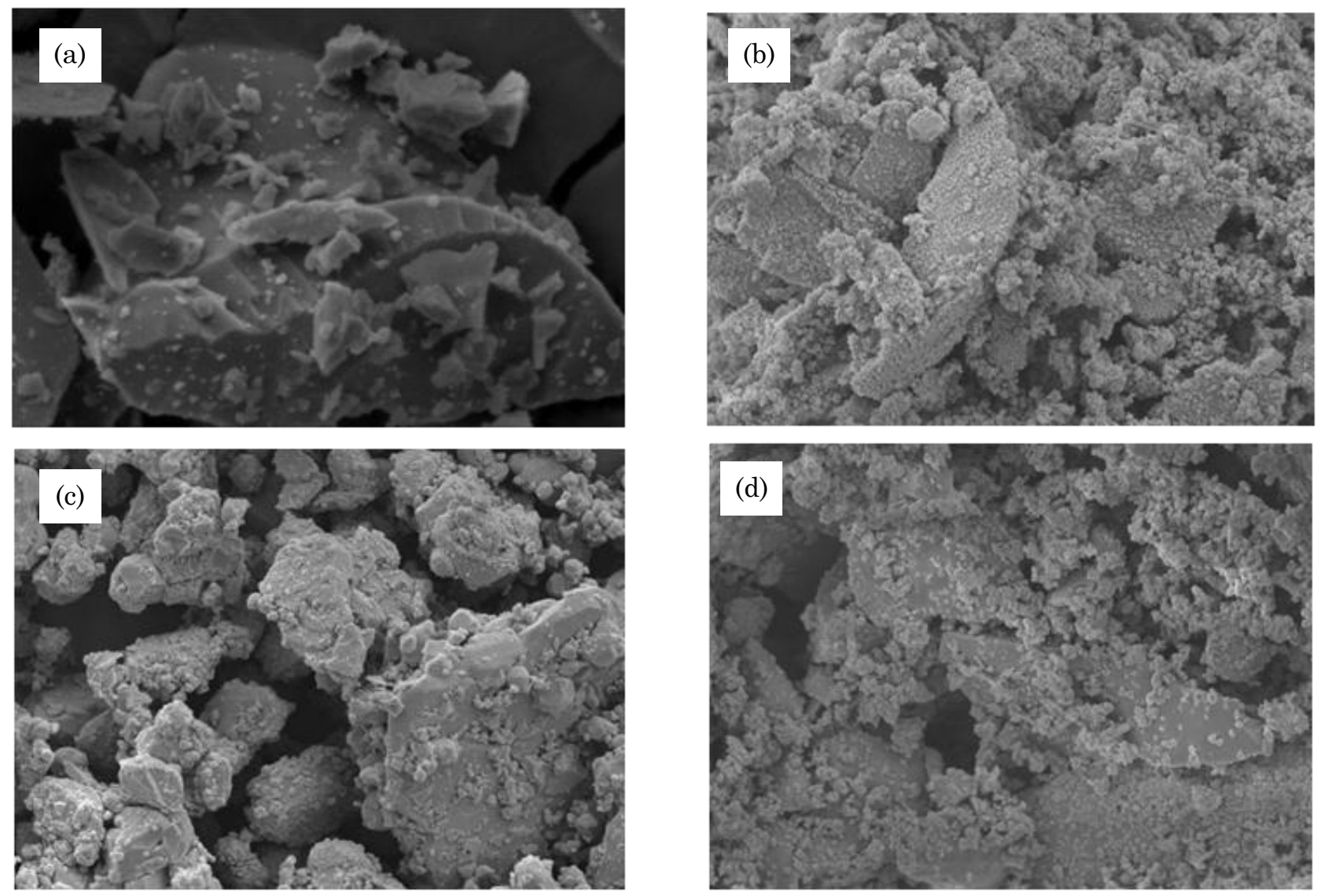

Figure 3. Morphology structure of (a) $\mathrm{SiO}_{2}$, (b) $\mathrm{Ni} / \mathrm{SiO}_{2}$, (c) $\mathrm{Ag}(1)-\mathrm{Ni} / \mathrm{SiO}_{2}$ and (d) $\mathrm{Ag}(5)-\mathrm{Ni} / \mathrm{SiO}_{2}$ at 5000 times magnification 


\subsection{Brunauer-Emmett-Teller (BET) sur- face area}

The analysis from nitrogen physisorption indicates the presence of mesoporous materials. Table 1 shows the BET surface and pore volume of calcined $\mathrm{SiO}_{2}$, unpromoted $\mathrm{NiSiO}_{2}$ and $\mathrm{Ag}(5)-\mathrm{Ni} / \mathrm{SiO}_{2}$. The BET surface area of $\mathrm{Ni} / \mathrm{SiO}_{2}$ and Ag promoted catalysts are less than calcined $\mathrm{SiO}_{2}$ support. Apparently, introduction of $\mathrm{Ag}$ promoter decreases the BET surface area. This data is resulted from the pores blockage by the metallic oxide and the promoter. Similar results were also found by Diaz et al. and Guo et al. [10, 11]. However, increasing of Ag loading significantly increases the BET surface area. $\mathrm{Ag}(5)-\mathrm{Ni} / \mathrm{SiO}_{2}$ has the highest surface area among the promoted catalysts.

\subsection{Thermogravimetric analysis (TGA)}

Calcination profiles of $\mathrm{Ni} / \mathrm{SiO}_{2}, \mathrm{Ag}(1)$ $\mathrm{Ni} / \mathrm{SiO}_{2}, \mathrm{Ag}(3)-\mathrm{Ni} / \mathrm{SiO}_{2}$ and $\mathrm{Ag}(5)-\mathrm{Ni} / \mathrm{SiO}_{2}$ pre- sented in Figure 4 shows three stages of weight loss between $300 \mathrm{~K}$ to $650 \mathrm{~K}$. Peaks formation between $300 \mathrm{~K}$ to $400 \mathrm{~K}$ are due to the removal of water vapour in the catalysts [12]. The second stage of weight loss is between $400 \mathrm{~K}$ and $523 \mathrm{~K}$, showing two peaks resulting from the dehydration of hydrated silicon oxide for the final formation of $\mathrm{SiO}_{2}$, which is correlated to XRD study. The final stage in between $523 \mathrm{~K}$ to $650 \mathrm{~K}$ reveals the transformation of $\mathrm{Ni}\left(\mathrm{NO}_{3}\right)_{2} .6 \mathrm{H}_{2} \mathrm{O}$ into $\mathrm{NiO}$ which is in agreement with the findings reported by Estelle et al. [13].

\subsection{Temperature-programmed reduction}

The TPR profiles of $\mathrm{Ni} / \mathrm{SiO}_{2}$ and $\mathrm{Ag}(3)$ $\mathrm{Ni} / \mathrm{SiO}_{2}$ are depicted in Figure 5. The peak detected at $650 \mathrm{~K}$ for both catalysts can be attributed to the reduction of $\mathrm{NiO}$ to $\mathrm{Ni}$ metal, which is consistent with the findings of Acrotumapathy et al. [14]. Both catalysts showed the ability to easily reduce due to the strong oxygen

Table 1. BET surface area and cumulative pore volume of the catalysts

\begin{tabular}{ccc}
\hline Catalyst & Surface area $\left(\mathrm{m}^{2} \mathrm{~g}^{-1}\right)$ & Pore volume $\left(\mathrm{cm}^{3} \mathrm{~g}^{-1}\right)$ \\
\hline $\mathrm{SiO}_{2}$ & 80.903 & 0.0113 \\
$\mathrm{Ni} / \mathrm{SiO}_{2}$ & 46.345 & 0.0111 \\
$\mathrm{Ag}(1)-\mathrm{Ni} / \mathrm{SiO}_{2}$ & 17.265 & 0.0090 \\
$\mathrm{Ag}(3)-\mathrm{Ni} / \mathrm{SiO}_{2}$ & 30.283 & 0.0101 \\
$\mathrm{Ag}(5)-\mathrm{Ni} / \mathrm{SiO}_{2}$ & 38.848 & 0.0101 \\
\hline
\end{tabular}

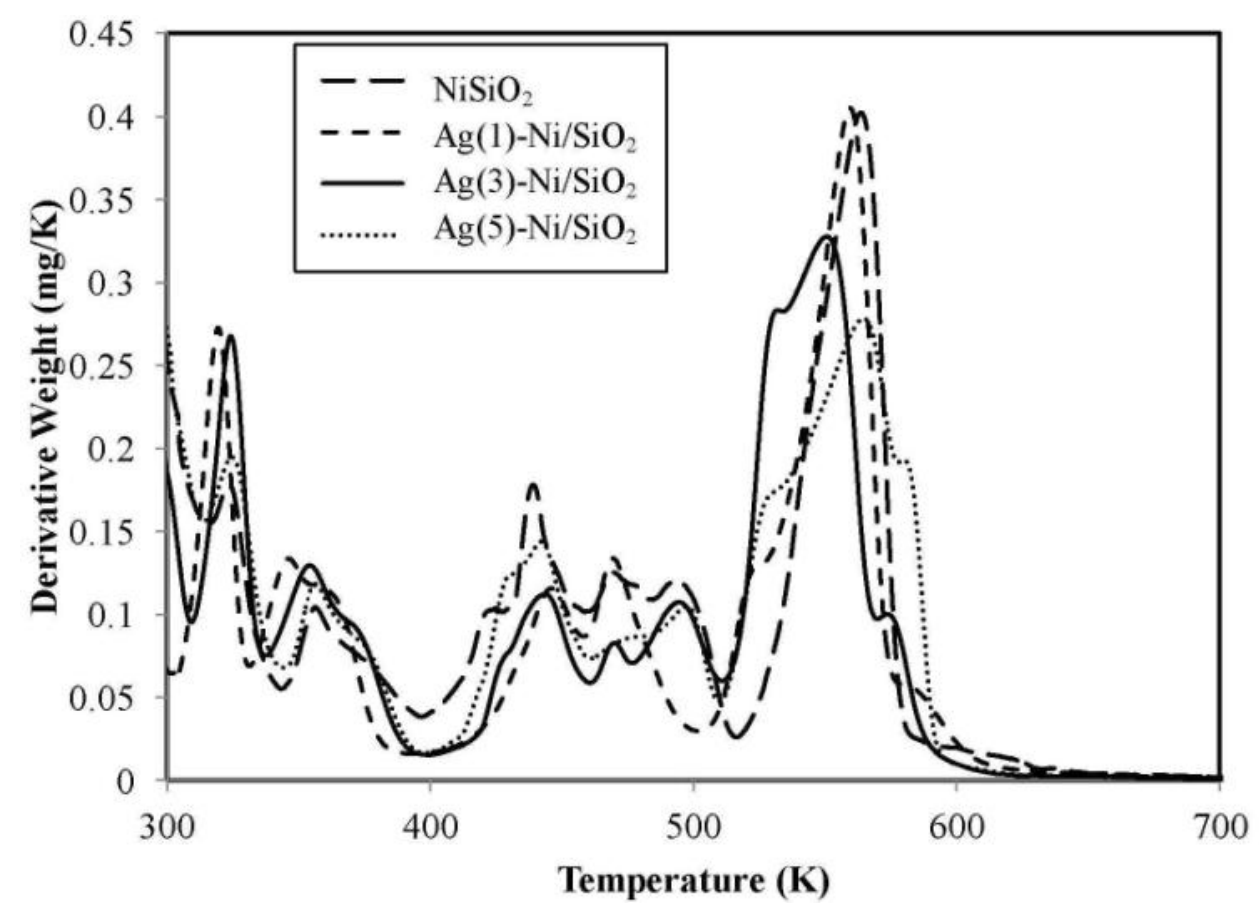

Figure 4. TGA analysis of catalysts at $10 \mathrm{~K} \mathrm{~min}^{-1}$ ramping rate in $\mathrm{N}_{2} / \mathrm{O}_{2}$ 
storage capacity in the catalyst. Because $\mathrm{H}_{2}$ completely reduced the catalyst at $773 \mathrm{~K}$, this temperature was selected as the reduction temperature for the catalysts during the reaction studies.

\subsection{Reaction study}

The glycerol dry reforming was conducted at a fixed condition with the reaction temperature of $973 \mathrm{~K}, 3 \mathrm{~h}$ reaction time, $1: 1$ carbon to glycerol ratio and at atmospheric pressure. Through the glycerol dry reforming, glycerol is converted into other gaseous products such as $\mathrm{H}_{2}, \mathrm{CH}_{4}$, $\mathrm{CO}, \mathrm{CO}_{2}$ and traces of gases.

From the glycerol conversion plot shown in Figure 6, an almost similar trend could be ob- served where the glycerol conversion are increases in the first 30 minute, decrease after 1 hour reaction time and stable along the reaction period. It is probably due to the deposition of carbonaceous species on the catalyst surface upon breakage of $\mathrm{C}-\mathrm{C}$ bond in glycerol. The highest glycerol conversion obtained over $\mathrm{Ag}(5)-\mathrm{Ni} / \mathrm{SiO}_{2}(32.1 \%)$ followed by other catalysts in descending $\mathrm{Ag}$ loading, which $\mathrm{Ni} / \mathrm{SiO}_{2}$ possess the least glycerol conversion of $6.5 \%$. This can be attributed to the high distribution of active sites and well dispersion of metallic $\mathrm{Ni}$ species on the catalyst surface, as indicated in XRD analysis. Furthermore, according to Jeong and Kang, addition of Ag contributes to higher reforming reactivity compared to unpromoted catalyst by reducing the degree of car-

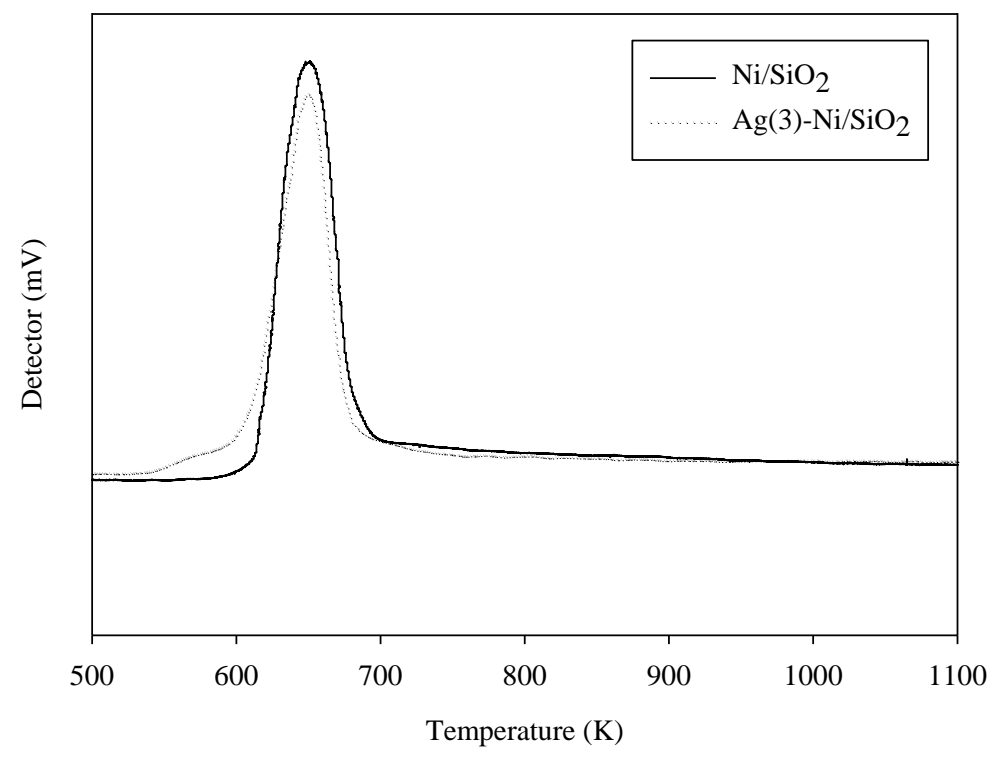

Figure 5. $\mathrm{H}_{2}-\mathrm{TPR}$ profile of $\mathrm{Ni} / \mathrm{SiO}_{2}$ and $\mathrm{Ag}(3)-\mathrm{Ni} / \mathrm{SiO}_{2}$ catalysts at heating rate of $10 \mathrm{~K} \mathrm{~min}^{-1}$

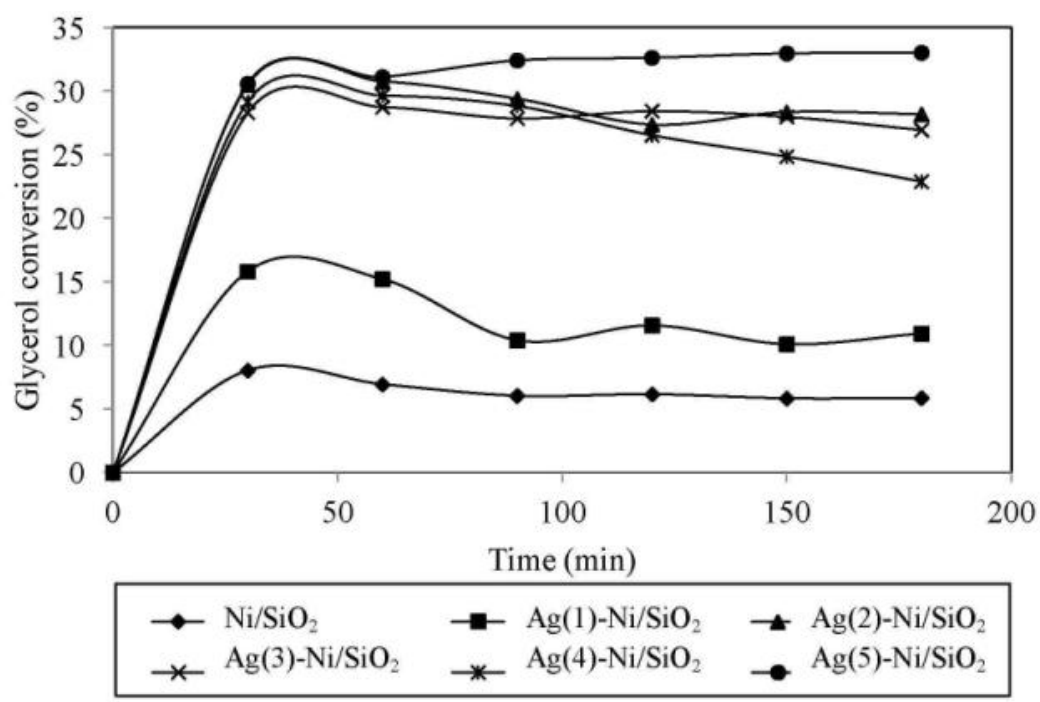

Figure 6. Glycerol conversion over 3 hours reaction time at $973 \mathrm{~K}, 1 \mathrm{~atm}$ and $\mathrm{CO}_{2}$ : Glycerol of 1:1 
bon deposition and improves hydrogen yield [15].

Figure 7 shows the products yield for different $\mathrm{Ag}$ loading at minute 90. The $\mathrm{Ag}(5)-\mathrm{Ni} / \mathrm{SiO}_{2}$ gives the highest hydrogen yield of $27.4 \%$ whereas $\mathrm{Ni} / \mathrm{SiO}_{2}$ produced the least yield of hydrogen accounted for $4.8 \%$. Methane yield is apparently lower than yield of hydrogen and carbon monoxide in the consecutive run. Methane is formed via dehydrogenation of glycerol, which also leads to the deposition of carbonaceous species [16]. Carbon monoxide yield is high for all the catalysts, circa 3 times the yield of hydrogen. High carbon monoxide content contributes to low hydrogen-to-carbon monoxide ratio as shown in Figure 8. Upon promotion with $\mathrm{Ag}$, the ratio is increased which 5\% $\mathrm{Ag}$ loading possess the highest ratio accounted for 4.0. This ratio is preferable for some synthesis such as production of aldehydes [3].

\subsection{Characterization of used catalyst}

There are several side reactions that may occur in the dry reforming of glycerol and affect

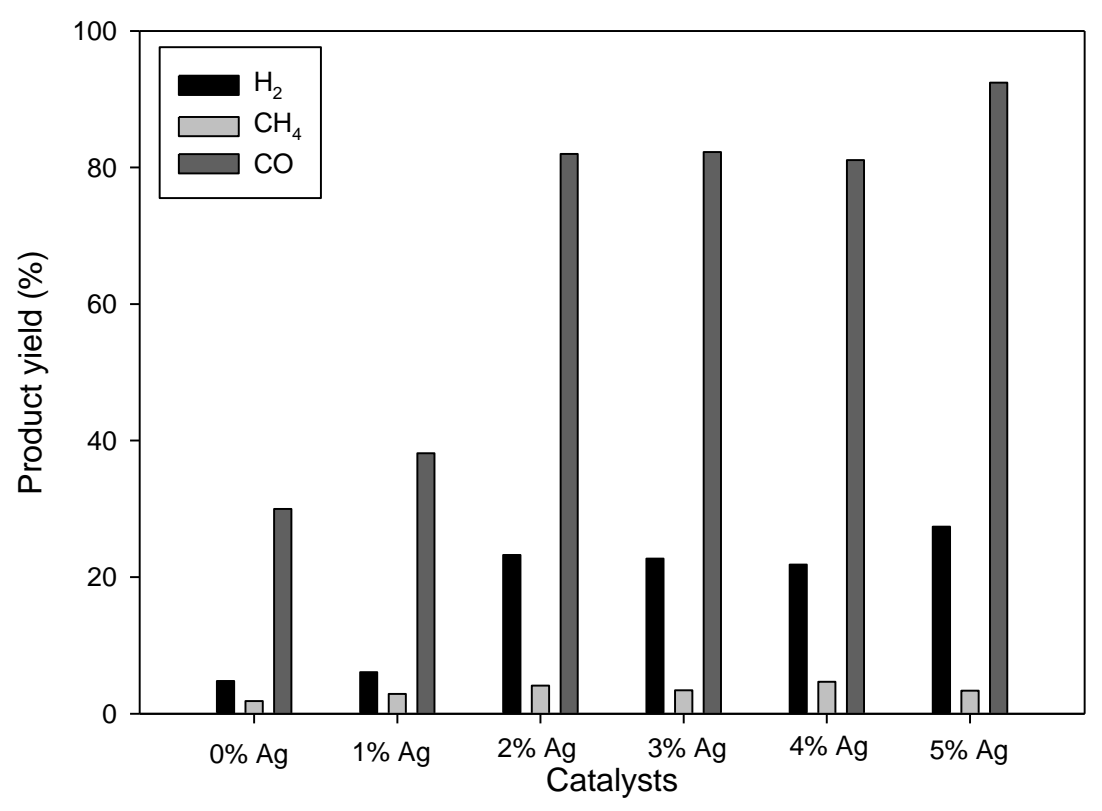

Figure 7. Hydrogen, methane and carbon monoxide yield for different Ag loading at $973 \mathrm{~K}, 1 \mathrm{~atm}$ and $\mathrm{CO}_{2}$ :Glycerol of 1:1

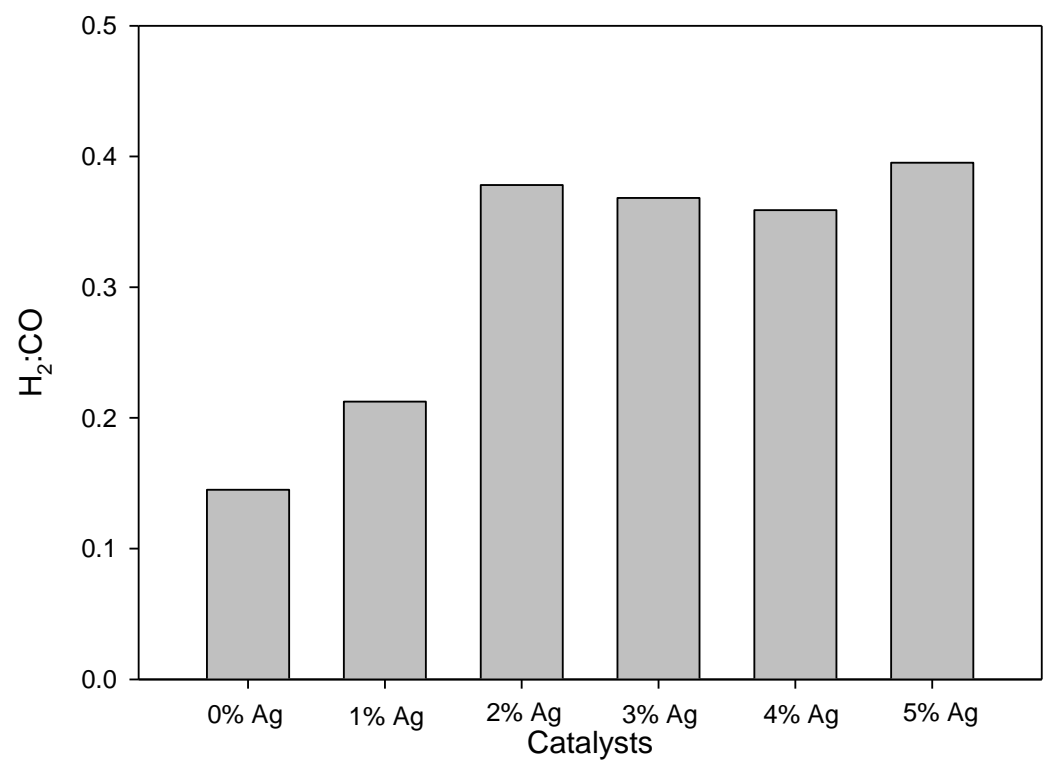

Figure 8. $\mathrm{H}_{2}: \mathrm{CO}$ products ratio as function of promoter loadings loading at $973 \mathrm{~K}, 1 \mathrm{~atm}$ and $\mathrm{CO}_{2}$ :Glycerol of $1: 1$ 

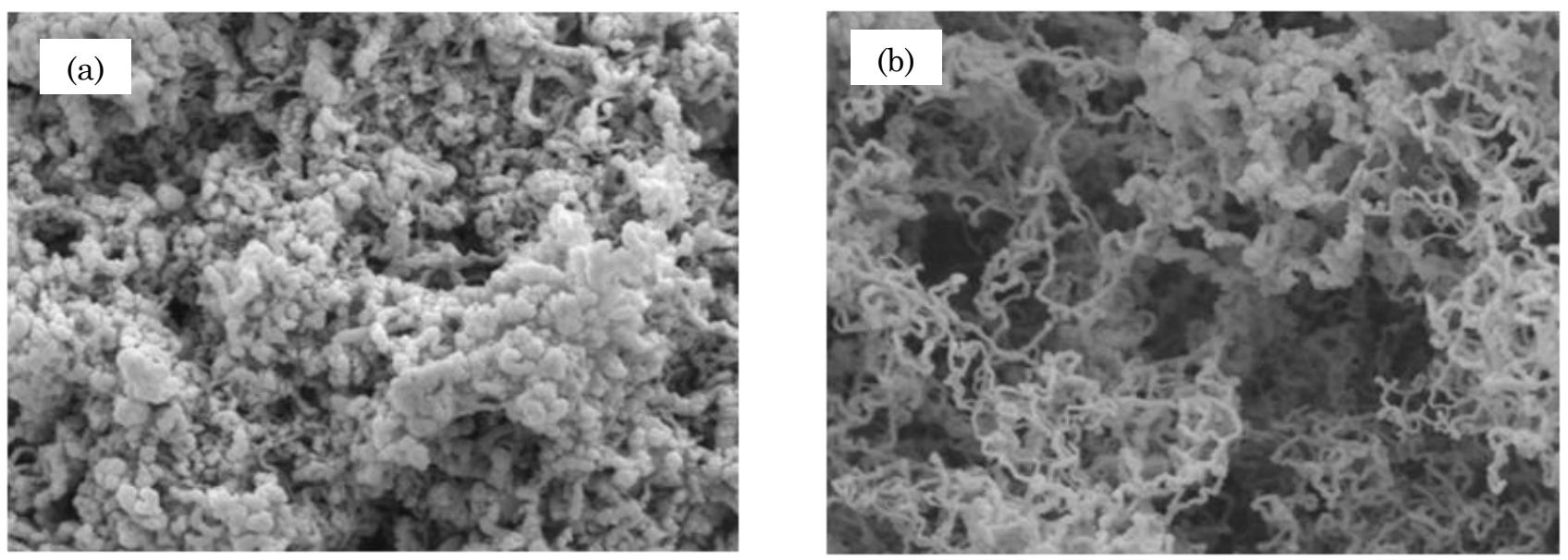

Figure 9. SEM image of the spent catalyst at 30,000X magnification

the catalyst performance. The carbon deposition phenomenon could be observed upon subjected the spent catalyst to SEM study. As shown in Figure 9, there are two types of carbon deposits. The first type is solid carbon deposited on the catalyst surface which covers the active sites of the catalyst as in Figure 9 (a). Another type is shown in Figure 9 (b), the filamentous-type (whisker-like) carbon deposition.

\section{Conclusions}

A series of silica-supported Ni based catalysts with different $\mathrm{Ag}$ promotion were prepared via wet impregnation method. Reaction studies at $1 \mathrm{~atm}, 973 \mathrm{~K}$ and $\mathrm{CO}_{2}$ :glycerol of 1:1 showed that glycerol dry reforming successfully produced syngas with $\mathrm{H}_{2}$ : $\mathrm{CO}$ molar ratio less than 1. Physicochemical characterization revealed that $\mathrm{Ag}$ promotion can enhance the formation of $\mathrm{Ag}$ phase crystallites and promotes the dispersion of $\mathrm{NiO}$ particles. Significantly, the $\mathrm{Ag}(5)-\mathrm{Ni} / \mathrm{SiO}_{2}$ catalyst, which possessed the highest Ag loading gave optimum glycerol conversion and hydrogen yield, accounted for $32.1 \%$ and $27.4 \%$, respectively. Through XRD analysis, it was found that $\mathrm{Ag}(5) \mathrm{NiSiO}_{2}$ has the smaller particles which indicates the fine dispersion of $\mathrm{NiO}$ particles. Moreover, data from BET surface area reveals that the highest surface area of $\mathrm{Ag}(5)-\mathrm{Ni} / \mathrm{SiO}_{2}$ among the $\mathrm{Ag}$ promoted catalysts. SEM analysis showed the rougher surface indicates the formation of $\mathrm{Ag}$ particles and $\mathrm{NiO}$.

\section{Acknowledgement}

Authors would like to thank MOE for awarding the FRGS research grant vote RDU130108 and Universiti Malaysia Pahang for financial support.

\section{References}

[1] Adhikari, S., Fernando, S., Gwaltney, S., Filipto, S., Markbricka, R., Steele, P. and Haryanto, A. (2007). A thermodynamic analysis of hydrogen production by steam reforming of glycerol. International Journal of $\mathrm{Hy}$ drogen Energy, 32(14): 2875-2880.

[2] Lin, Y.C. (2013). Catalytic valorization of glycerol to hydrogen and syngas. International Journal of Hydrogen Energy, 38(6): 2678-2700.

[3] Wang, X., Li, M., Wang, M., Wang, H., Li, S., Wang, S. and Ma, X. (2009). Thermodynamic analysis of glycerol dry reforming for hydrogen and synthesis gas production. Fuel, 88(11): 2148-2153.

[4] Lee, H. C., Siew, K. W., Gimbun, J. and Cheng, C. K. (2013). Application of Cement Clinker as Ni-Catalyst Support for Glycerol Dry Reforming. Bulletin of Chemical Reaction Engineering \& Catalysis, 8(2): 137-144.

[5] Siew, K.W., Lee, H.C., Gimbun, J. and Cheng, C. K. (2014). Characterization of La-promoted $\mathrm{Ni} / \mathrm{Al}_{2} \mathrm{O}_{3}$ catalysts for hydrogen production from glycerol dry reforming. Journal of Energy Chemistry, 23(1): 15-21.

[6] Parizotto, N.V., Rocha, K.O., Damyanova, S., Passos, F.B., Zanchet, D., Marques, C.M.P. and Bueno, J.M.C. (2007). Aluminasupported Ni catalysts modified with silver for the steam reforming of methane: Effect of $\mathrm{Ag}$ on the control of coke formation. Applied Catalysis A: General, 330:12-22

[7] Yu, M., Zhu, Y., Lu, Y., Tong, G., Zhu, K. and Zhou, X. (2015). The promoting role of $\mathrm{Ag}$ in $\mathrm{Ni}-\mathrm{CeO}_{2}$ catalyzed $\mathrm{CH}_{4}-\mathrm{CO}_{2}$ dry reforming reaction. Applied Catalysis B: Environmental, 165 (2015): 43-56. 
[8] Chen, M., Zhang, D., Thompson, L.T. and Ma, Z. (2011). Catalytic properties of Ag promoted $\mathrm{ZnO} / \mathrm{Al}_{2} \mathrm{O}_{3}$ catalysts for hydrogen production by steam reforming of ethanol. International Journal of Hydrogen Energy, 36: 7516-7522.

[9] Siew, K.W., Lee, H.C., Gimbun, J. and Cheng, C.K. (2013). Hydrogen production via glycerol dry reforming over La-Ni/Al ${ }_{2} \mathrm{O}_{3}$ catalyst. Bulletin of Chemical Reaction Engineering \& Catalysis, 8(2): 160-166.

[10] Diaz, G.C., Tapanes, N.C.O., Camara, L.D.T and Aranda, D.A.G. (2014). Glycerol conversion in the experimental study of catalytic hydrolysis of triglycerides for fatty acids production using $\mathrm{Ni}$ or $\mathrm{Pd}$ on $\mathrm{Al}_{2} \mathrm{O}_{3}$ or $\mathrm{SiO}_{2}$. Renewable Energy, 64: 113-122

[11] Guo, J., Hou, Z., Gao, J. and Zheng, X. (2008). Syngas production via combined oxy- $\mathrm{CO}_{2}$ reforming of methane over $\mathrm{Gd}_{2} \mathrm{O}_{3}$-modified $\mathrm{Ni} / \mathrm{SiO}_{2}$ catalysts in a fluidized-bed reactor. Fuel, 87(7): 1348-1354.

[12] Alhassan, F.H., Rashid, U., Al-Qubaisi, M.S., Rasedee, A. and Taufiq-Yap, Y.H. (2014). The effect of sulfate contents on the surface properties of iron-manganese doped sulfated zirconia catalysts. Powder Technology. 253: 809813
[13] Estellé, J., Salagre, P., Cesteros, Y., Serra, M., Medina, F.,\& Sueiras, J.E. (2003). Comparative study of the morphology and surface properties of nickel oxide prepared from different precursors. Solid State Ionics, 156: 233-243.

[14] Acrotumapathy, V., Dai-Viet, N. V., Chesterfield, D., Cao, T. Tin, Siahvashi, A., Lucien, F.P., and Adesina, A.A. (2014). Catalyst design for methane steam reforming. Applied Catalysis A: General. 479: 87-102.

[15] Jeong, H and Kang, M. (2010). Hydrogen production from butane steam reforming over $\mathrm{Ni} / \mathrm{Ag}$ loaded $\mathrm{MgAl}_{2} \mathrm{O}_{4}$ catalyst. Applied Catalysis B: Environmental, 95(3-4): 446-455.

[16] Siew, K.W., Lee, H.C., Gimbun, J. and Cheng, C. K. (2014). Production of CO-rich hydrogen gas from glycerol dry reforming over Lapromoted $\mathrm{Ni} / \mathrm{Al}_{2} \mathrm{O}_{3}$ catalyst. International Journal of Hydrogen Energy, 39: 6927-6936.

Selected and Revised Papers from The International Conference on Fluids and Chemical Engineering (FluidsChE 2015) (http://fluidsche.ump.edu.my/index.php/en/) (Malaysia, 25-27 November 2015) after Peer-reviewed by Scientific Committee of FluidsChE 2015 and Reviewers of BCREC 